Newfoundland and Labrador Studies

\title{
Antony Berger, editor. No Place for a Woman: The Life and Newfoundland Stories of Ella Manuel
}

\section{Quinn Anderson}

Volume 36, numéro 1, 2021

URI : https://id.erudit.org/iderudit/1082216ar

DOI : https://doi.org/10.7202/1082216ar

Aller au sommaire du numéro

Éditeur(s)

Faculty of Arts, Memorial University

ISSN

1719-1726 (imprimé)

1715-1430 (numérique)

Découvrir la revue

Citer ce compte rendu

Anderson, Q. (2021). Compte rendu de [Antony Berger, editor. No Place for a Woman: The Life and Newfoundland Stories of Ella Manuel]. Newfoundland and Labrador Studies, 36(1), 130-133. https://doi.org/10.7202/1082216ar d'utilisation que vous pouvez consulter en ligne.

https://apropos.erudit.org/fr/usagers/politique-dutilisation/ 
BOOK REVIEWS

Antony Berger, editor. No Place for a Woman: The Life and Nerwfoundland Stories of Ella Manuel. St. John's: Breakwater Books, 2020. ISBN 978-1-55081-836-9

The adventurous, the humorous, the thrilling, and the mundane of Ella Manuel's plethora of stories, most of which previously unpublished, find a good home in this collection. Compiled, edited, and introduced by her son and acclaimed scholar Antony Berger, No Place for a Woman displays an intimate interplay between cherished memories and recently uncovered understandings. This interplay is especially present in part one of the book and attests to Berger's writing skill as he seamlessly integrates his own and his mother's points of view, establishing a metanarrative that is not easily achieved. Bringing together these two worlds, Berger lifts the story into an arena almost suspended of time that acknowledges the personal endeavour on his part to learn of and give proper interpretation to the most intimate thoughts of a loved one, and of one with so much to say, such as Ella.

Ella Manuel (1911-1985) led a remarkable life. Born in Lewisporte, Newfoundland, to local hotel owners Robert William Manuel and Jessie Sophia Reader, Ella studied at Boston University and graduated with a B.Sc. in Chemistry in 1931. Looking for work, she moved to England in 1933 where she would marry Joe Berger and birth two sons. After the family relocated to the United States at the start of the war, Ella happily returned to Newfoundland with her sons in 1944. She divorced Berger the following year and pursued a career in writing and broadcasting in western Newfoundland.

The ideas presented through her words and labours reflect this 
picture of a proud Newfoundland woman who never shied away from her identity. Not without tribulation, her experiences and interactions with her contemporaries offer readers a look into the life of one who did not allow the social expectations of her gender to deter from her goals or diminish her accomplishments. Underlining her staunch and enduring mission for equality and her devotion to the women of Newfoundland, Ella served as national vice-president of the Voice of Women (VOW) in the 1960s, she crafted a letter detailing the condition of women in Newfoundland to the Royal Commission on the Status of Women, and she frequently depicts wilfully determined women and girls in both her published and unpublished works. Though she has since seldom been acknowledged for her efforts as an activist, this work offers intimate insight into how she not only professed but lived her convictions as a feminist. The relationship between Ella and Emma Tapper presented in "My Killdevil Days," "Building My House on the Hill," and "The Wonderful Emma Tapper" is unapologetically intimate and shows the importance of such a relationship between such unconventional people. Emma Tapper was without a doubt a source of unending support and inspiration to Ella. The tales of these two remove the singularity and exceptionalism of Ella's independence. This does not diminish her accomplishments, but rather instills in the reader an understanding of the networks required for such work and the changing gendered landscape of the period. An eye-opening account into the lives of Newfoundland women, Ella Manuel's recollections and stories can now be thoroughly explored and incorporated into the history of Newfoundland feminism.

Aside from her achievements and strides in feminism, her lovingly and expertly crafted depictions of Newfoundland are that of a skilled storyteller. The feeling of wonder and constant admiration of the natural beauty that captivates visitors and locals alike is a testament to Ella's artistry and appreciation of her surroundings. Foreshadowing the creation of Gros Morne National Park and the now endless activities available to those outdoor types, Ella's adventures and recollections in the chapters "Lomond" and "Woody Point" attest to her 
appreciation of the striking natural beauty of the province. While much of Ella's depiction of the landscape has remained unchanged, readers are given a glimpse into the precipitate developments occurring during this period.

Memories of resettled communities given new life; roads connecting those once entirely isolated; power lines offering new light (and Ella a headache): all these changes are eloquently described as seen through her eyes. The changes that occur during Ella's time in Newfoundland are a prominent feature of her stories and a theme throughout the text. Far from depicting a backward, underdeveloped province in desperate need of modernization, as some narratives purport, Ella dismisses notions of a "simple life" and presents the intricacies of both the advantages and disadvantages of living on the island. Episodes delineating the adjustment from old to new give readers an interesting glance into the world view of those in the midst of these transformations. "The New Road Northward" describes how the roads connecting those on the Northern Peninsula to the rest of the province affected their way of life. While it did offer solace to have easier access to doctors, mail, and supplies, Ella is concerned with the introduction of a consumer culture that may, in her view, lead to the deterioration of the knowledge of self-sustainability that she and many others rely on and relish in. While not ignorant to the many improvements accompanying these changes, Ella, throughout her writings, does seem concerned with this loss of cultural knowledge, a loss that is studied and characterized within much of the scholarship of Newfoundland historians and folklorists. While there has been a waning of or a shift in such work, efforts are still being made to preserve local know-how; a recent book, Towards an Encyclopedia of Local Knowledge by Pam Hall, co-published by Breakwater Books in 2017, presents a collection of written and visual representations of these proficiencies. Ella's stories thus produce an indispensable cache of the contemporary perceptions and consequences of these changes.

Offering insight into the lives of myriad friends, neighbours, celebrities, and scholars, Ella's portrayals of people radiate with keen 
attention to detail that balances her ability as a trained writer with the retention and appreciation for local dialect. Her depictions of landscape paint picturesque scenes of expansive variety that reflect her skills in poetry and love of the island's natural settings. Berger's book is thus a tribute to Ella Manuel, a "teller of tales of yesterday," that stands as an acknowledgement to her wondrous storytelling, compelling insight, and adventurous, resolute feminist lifestyle. Ella saw little public recognition for her prose aside from her political writings. In publishing a compilation of her writings and manuscripts, Berger succeeds in what Ella did not. The gaps between the jagged edges her stories had left were not to be filled with more of the same; the broken pot would instead be made whole with the powerful legacy of Ella herself.

Quinn Anderson McMaster University 